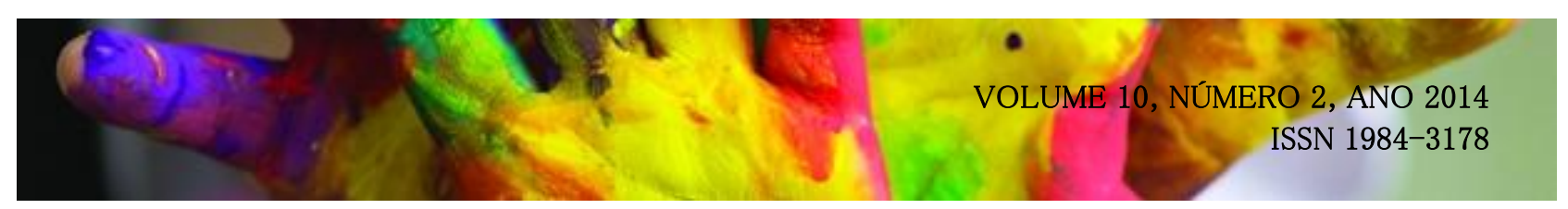

\title{
LIBRÁRIO: LIBRAS PARA TODOS
}

DOI: http://dx.doi.org/10.5965/19843178102201477

\author{
Rita de Castro Engler ${ }^{1}$ \\ Flavia Neves de Oliveira ${ }^{2}$ \\ Nadja Maria Mourão ${ }^{3}$
}

\section{RESUMO}

A língua de sinais é uma língua bela e expressiva, que possibilita a comunicação uns com os outros, com facilidade e rapidez para a interpretação da mente dos surdos, afirmou Long (1910). Na prática, existe grande dificuldade e falta de preparo por parte da população, para lidar com os surdos. A pesquisa procura investigar e propor soluções, para suprir as necessidades educacionais dos deficientes auditivos e expandir a língua de sinais. No ambiente de ensino questões como espaço e posicionamento dos alunos são cruciais para o estudante surdo. A metodologia utilizada foi de pesquisa-ação, que em contato com o universo dos surdos, proporcionou um panorama da necessidade de comunicação mais eficiente, e a possibilidade dos ouvintes aprenderem Libras. Foi desenvolvido um jogo para incentivar o uso da "Libras", de forma lúdica. O jogo "Librário" é constituído de um baralho de pares de cartas, contendo os sinais de Libras e as palavras em português, possibilitando o aprendizado de sinais para ouvintes. Foram desenvolvidas oficinas de arte educação para jovens, viabilizando a comunicação entre os participantes. Essa troca permite o aprendizado de forma divertida, como o estreitamento de laços entre a comunidade, onde todos estão incluídos.

Palavras-chave: Arte, design inclusivo, deficiente auditivo, educação.

1 PhD em Gestão da Inovação Tecnológica. Ecole Centrale Paris/França e Pós-doutorado em Design social e inclusivo Ryerson University/Canadá; Escola de Design. UEMG/ CEDTec - Centro de Estudos em Design e Tecnologia/Coordenadora geral. Avenida Presidente Antônio Carlos, 7545, Bairro São Luís, BH, MG (rsengler@uol.com.br).

2 Graduanda em Artes Visuais Licenciatura. Escola de Design. UEMG/ CEDTec - Centro de Estudos em Design e Tecnologia/Bolsista Fapemig. Avenida Presidente Antônio Carlos, 7545, Bairro São Luís, BH, MG (eudisseflavia@gmail.com).

3 Mestra em Design, Inovação e Sustentabilidade. Escola de Design. UEMG/ CEDTec - Centro de Estudos em Design e Tecnologia/Coordenadora de projetos. Avenida Presidente Antônio Carlos, 7545, Bairro São Luís, BH, MG (nadjamourao@gmail.com). 


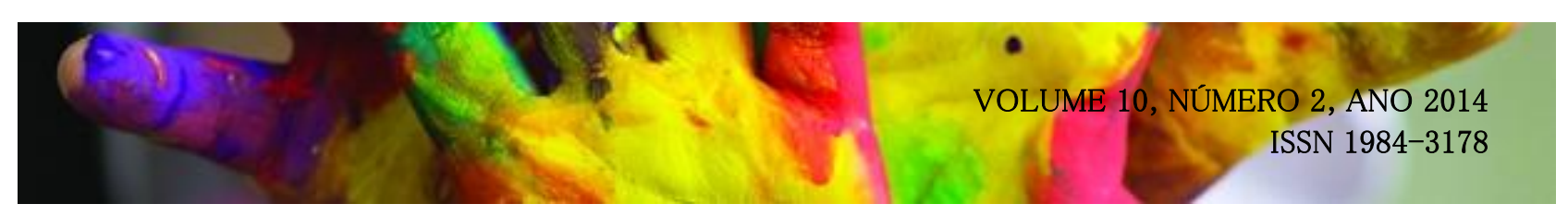

\title{
LIBRÁRIO: LIBRAS FOR ALL
}

\begin{abstract}
Sign language is a beautiful and expressive language, which enables communication with each other, easily and quickly for the interpretation of the deaf mind, said Long (1910). In practice, there is great difficulty and lack of preparation on the population side, to deal with Deaf. The research seeks to investigate and propose solutions to meet the educational needs of Deaf and expand sign language. In the learning environment issues such as space and placement of students are crucial to Deaf students. The methodology used was action research, which in contact with the Deaf world, provided an overview of the need for more efficient communication, and the ability of listeners learn LIBRAS. A game was designed to encourage the use of "LIBRAS" in a funny way. The

"Librário" game consists of a deck of cards pairs, containing LIBRAS signs and words in

Portuguese, helping listeners to learn how to sign. Art education workshops for youth were developed, enabling the communication between the participants. This exchange allows learning in a fun way, stronger ties between communities where everyone is included.
\end{abstract}

Keywords: Art, inclusive design, Deaf, education.

\section{INTRODUÇÃO: DA TECNOLOGIA AO DESIGN INCLUSIVO}

A descoberta do fogo, a invenção da roda e a escrita são tecnologias que proporcionaram a evolução da humanidade. Os avanços tecnológicos resultaram em inovações que proporcionam melhoria na qualidade de vida dos seres humanos.

A palavra tecnologia tem origem no grego "tekhne" que significa "técnica, arte, ofício", é um estudo de uma técnica, que remete ao aprimoramento de um ofício. Cientificamente é definida como um conjunto de instrumentos, métodos e técnicas que visam à resolução de problemas. Ou seja, tecnologia é uma aplicação prática do conhecimento científico em diversas áreas de pesquisa, 


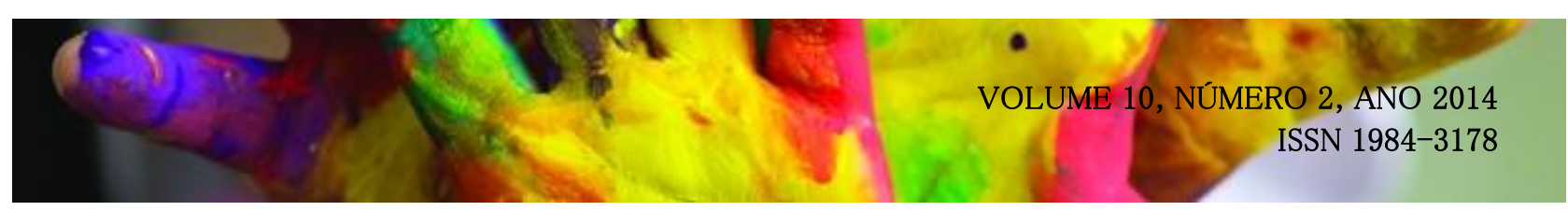

conforme Mourão (2011).

Dagnino (2004) esclarece que, a maneira como se organiza o trabalho (orgware), o substrato tecnológico (hardware e software), somados ao substrato científico, de alguma maneira, produzem a tecnologia em constante processo de transformação.

A partir desse conceito, o projeto base desta pesquisa, "Design Digital para Inclusão de deficientes auditivos", fomento da Fapemig - Fundação de Amparo à Pesquisa do Estado de Minas Gerais, pelo edital 13/2012 - Pesquisa em Educação Básica - Capes/Fapemig, busca refletir sobre os métodos, instrumentos imagéticos e técnicas que auxiliem os surdos à compreenderem o mundo ao seu redor e a serem compreendidos dentro de um contexto escolar e social heterogêneo.

No primeiro ano da pesquisa, foram realizados registros da revisão bibliográfica e dos métodos de ensino para surdos, inclusão digital e análises, na perspectiva do design, conteúdos do artigo "Contribuições do design digital para a inclusão de deficientes auditivos". Foram elencados resultados de tecnologias assistivas em produtos tangíveis e inovadores, advindos de conhecimentos e práticas da tecnologia e do design digital e social.

Os estudos se fundamentam nas reflexões sobre linguagem, apresentados por Corsino (2003), inspirado na filosofia de Walter Benjamin, que defende que a linguagem como "a casa das ideias"- é através da palavra que as ideias podem ser formuladas a nós mesmos e ao outro. Ou seja, a realidade nos é apresentada pela linguagem, ela existe e se expressa na língua, nos possibilitando também conhecê-la e expressá-la, conforme Corsino (2003).

Duarte Junior relata que um símbolo constitui um objeto ou sinal representativo de algo, em determinado tempo e cultura. Ou seja, "por intermédio dos símbolos o mundo pode ser apreendido como uma totalidade, já que eles permitem a reunião e o entrelaçamento de objetos e fatos ausentes (e mesmo díspares), na consciência humana” (DUARTE JUNIOR, 1991, p. 26).

Neste artigo, propõe-se apresentar os resultados da proposta inclusiva, resultante no desenvolvimento de um jogo intitulado: "Librário - o jogo de baralho da linguagem visual". Este jogo busca estimular a aprendizagem da primeira língua dos Surdos, Libras, que é uma língua visual 


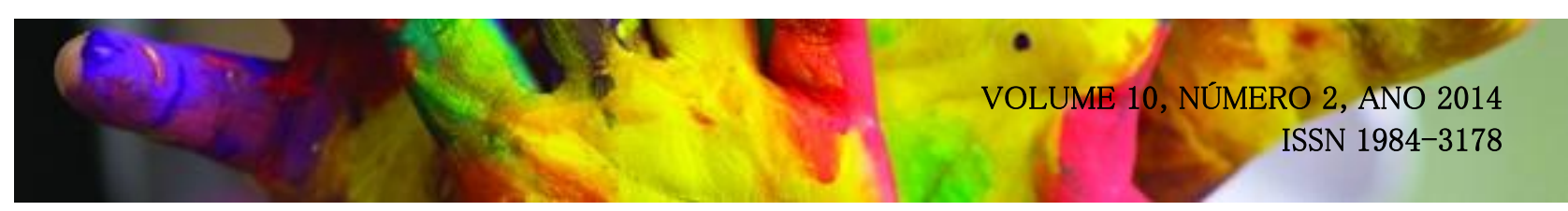

- motora e enfatiza a relação entre palavra em Português, imagem como símbolo e sinal. $\mathrm{O}$ estudo se apropriou da forma americana "Deaf", "Surdos", para denominar todos aqueles que possuem diferentes graus de deficiência auditiva, em especial neste trabalho, aos totalmente surdos.

Como norteador, utilizou-se da lógica reversa, estimular a aprendizagem da língua Libras pelos ouvintes ao contrário do caminho mais comum que é o da oralização do Surdo. É importante ressaltar que a Libras é a segunda língua oficial do território brasileiro, conforme a Lei n. 10.436, de 24 de abril de 2002:

Art. $1^{\circ}$ - É reconhecida como meio legal de comunicação e expressão a Língua Brasileira de Sinais - Libras e outros recursos de expressão a ela associados.

Parágrafo único. Entende-se como Língua Brasileira de Sinais - Libras a Parágrafo único. Entende-se como Língua Brasileira de Sinais - Libras a forma de comunicação e expressão, em que o sistema linguístico de natureza visual-motora, com estrutura gramatical própria, constitui um sistema linguístico de transmissão de ideias e fatos, oriundos de comunidades de pessoas surdas do Brasil. (BRASIL, 2002).

Oficialmente, os surdos devem a receber uma educação bilíngue e aprender o português nas escolas. Aos ouvintes, na grande maioria das escolas de ensino fundamental, não é oferecida a possibilidade de aprender Libras, apesar de não haver qualquer impedimento físico que dificulte a assimilação dos sinais por estes estudantes.

Como objetivos secundário espera-se possibilitar aos ouvintes o acesso a uma parte do vocabulário da Libras de forma dinâmica através do jogo; incentivar o reconhecimento da relação coerente entre palavra, imagem e sinal dentro do campo da arte; contextualizar as experiências da cultura e comunicação da comunidade surda, com recursos de imagens e contribuir para a integração entre surdos e ouvintes efetivamente.

Para aplicação do jogo, optou-se por ambientes com a participação de surdos e não surdos, em especial em escola inclusiva, especificamente na sala que tenham discentes ouvintes e Surdos e em cursos de Libras para discentes em Licenciatura ou não.

O método aplicado para o desenvolvimento do Librário é a pesquisa-ação, tipo de pesquisa social baseado na experiência. Este método é concebido e realizado em estreita associação com uma 


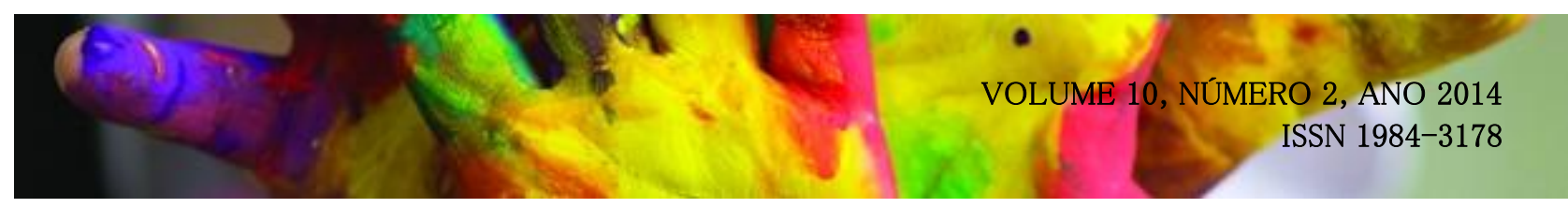

ação ou com a resolução de um problema coletivo, no qual os investigadores e os participantes circunstanciais estão envolvidos de modo cooperativo ou participativo, conforme Vergara (2004). Desta forma, o Librário foi desenvolvido por experimentação em situação real, com a participação dos investigadores em consulta permanente aos professores de Libras e aos Surdos.

\title{
2. A IMPORTÂNCIA DO LÚDICO E DA ARTE NA COMUNICAÇÃO
}

A língua de sinais é uma língua extremamente dinâmica e expressiva, possibilitando a comunicação uns com os outros, com facilidade e rapidez para a interpretação da mente dos surdos, afirma Long (1910). Para o autor, as imagens reveladas em gestos proporcionam um efeito de realização aos surdos, pois nem a natureza ou a arte lhes concedeu um substituto à altura.

\begin{abstract}
Para aqueles que não a entendem, é impossível perceber suas possibilidades para os surdos, sua poderosa influência sobre moral e a felicidade social dos que são privados da audição e seu admirável poder de levar o pensamento a intelectos que de outro modo estariam em perpétua escuridão, Tão pouco são capazes de avaliar o poder que ela tem sobre os surdos. Enquanto houver duas pessoas surdas sobre a face da terra e elas se encontrarem, serão usados sinais ${ }^{4}$ (LONG, 1910, apud SACKS, 1998, p. 5).
\end{abstract}

Segundo Botelho (2009), não ter uma língua compartilhada define uma situação de desigualdade cognitiva e interativa imensa. O surdo compreende e interage com o mundo por meio de experiências visuais, não compartilha da mesma linguagem dos ouvintes, isso se torna um desafio para educação, conduzir positivamente essa diferença reconhecendo que a linguagem é um fator fundamental ao desenvolvimento cognitivo do sujeito sociocultural.

A Libras é a língua brasileira de sinais e esta sigla foi criada em 1994, pela própria comunidade surda. A aprendizagem da Libras, por muito tempo, não foi valorizada pela sociedade. Somente em 2002, foi decretada como forma oficial de comunicação dos surdos.

Em 2005, foi inserida como disciplina curricular obrigatória nos cursos de formação de

4 J. Schuyler Long - Diretor da Iowa School for the Deaf. In: The Sign Language (1910). 


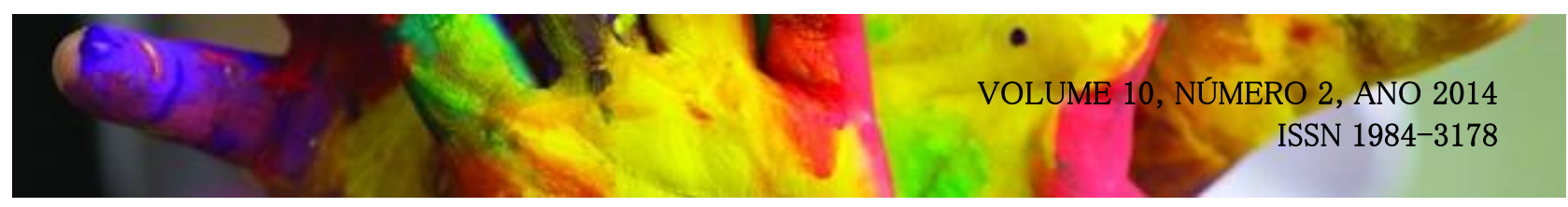

professores e estipuladas às obrigações de seus intérpretes em sala de aula, em 2010. Observa-se que nos últimos anos, houve muitas conquistas dos Surdos no âmbito educacional.

Faz-se necessário esclarecer a arte no que tange às questões dicotômicas que adentram o território da emoção, razão, afetividade e cognição, ou seja, seres humanos dotados de uma totalidade de subjetividades e objetividades. Duarte Junior (1991) elucida que a arte nos acompanha desde as cavernas, que também definiu a linguagem como código simbólico. Isto quer dizer que as palavras (símbolos) são utilizadas para transmitir um determinado significado. Ou seja, toda comunicação carrega em si expressões, símbolos e significações. E dentro desse panorama social e simbólico, as diretrizes educacionais estão muito presas aos padrões culturais dos ouvintes.

O surdo tem sua própria cultura, sendo assim, subcultura da cultura brasileira, ou seja, um grupo minoritário de pessoas, com sua língua própria, uma subdivisão dentro de uma cultura dominante da sua comunidade, no território brasileiro. E é na educação inclusiva que podemos fazer a manutenção dessas diferenças.

Sabe-se que o homem é um ser de símbolos e a arte possui o poder de ampliar a participação do individuo como cidadão. Conforme Liavelberg (2003), a arte "pode compartilhar de um modo de interação único no meio cultural", e pela leitura de imagem desenvolvemos a percepção, identificação e interpretação.

\section{LIBRÁRIO - O JOGO DA LINGUAGEM VISUAL}

Na busca da compreensão do universo dos Surdos, reflete-se sobre o contexto simbólico das palavras de Manoel de Barros, ao se referir à importância da imagem na arte: "Imagens são palavras que nos faltaram" (BARROS, 1998). Piaget (1994) ressalta a importância pedagógica dos jogos ao demonstrar a estreita relação entre o jogo e os mecanismos envolvidos na construção da inteligência.

De acordo com Duarte Júnior (2004), o homem iniciou sua existência ludicamente, 


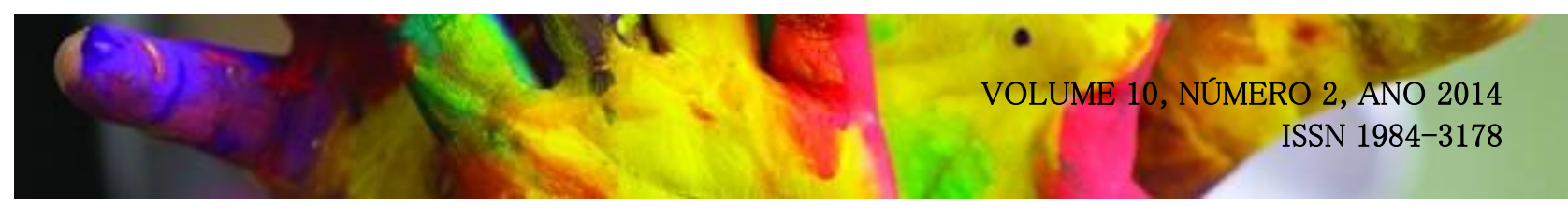

utilizando os recursos que se encontravam em torno de si, numa ordem que dava sentido à sua ação, o que significou a criação da cultura. $\mathrm{O}$ jogo, de maneira lúdica trabalha com regras e nos faz constatar que a lógica do brinquedo como ferramenta pedagógica está nas origens das construções humanas e "é uma ação que não produz nada, em termos materiais, que não tem um fim exterior a si próprio: suas finalidades residem nele mesmo" (DUARTE JUNIOR, 2004, p.51).

Duarte Júnior (2004) estuda a linguagem e a criação da cultura e afirma que no jogo é estruturada a ordem e equilíbrio, através da atuação do corpo. Esclarece que suas regras, ao serem criadas e seguidas, permitem que o homem se envolva numa ação prazerosa por si própria.

Sob a ótica dos autores citados, selecionaram-se algumas palavras de maior usabilidade no ensino, para experimentação em representação fotográfica do gesto. Assim, para cada carta com um desenho figurativo de um objeto, produzimos outra carta com a imagem fotográfica do sinal, na língua da Libras. No desenvolvimento do jogo de Libras - Librário, figura 1, enfatiza-se a linguagem como instrumento básico para a significação, dos objetos em palavras.

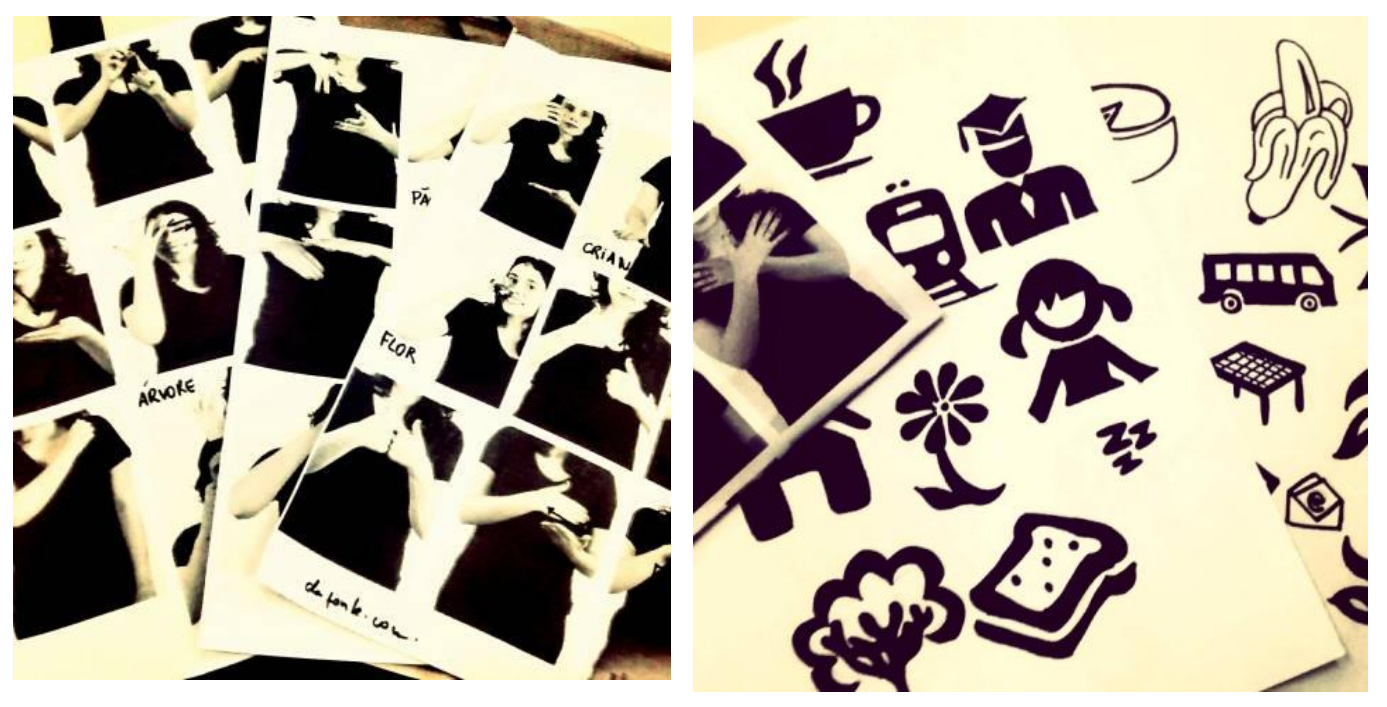

Figura 1: Registro do processo de criação do Librário. Fonte: Acervo da pesquisa, 2013.

O jogo educativo "Librário" foi inspirado no jogo do grupo NAD (National Asoociation of the deaf) estruturado em ASL (American Sign Linguage), linguagem original em inglês. A 


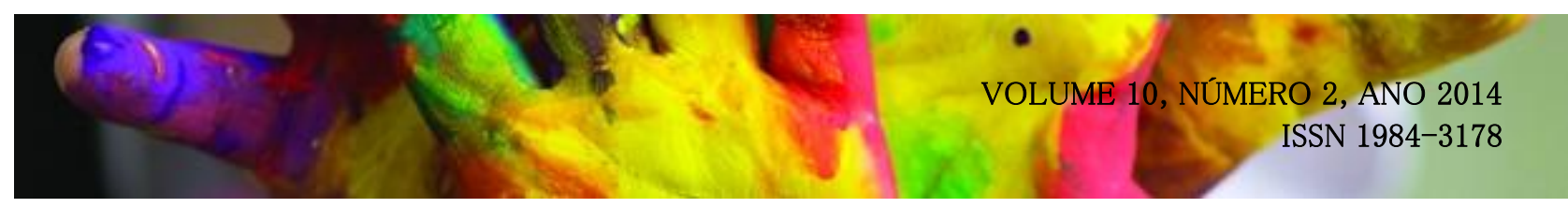

pesquisadora Dr $^{\mathrm{a}}$ Rita Engler, professora convidada da Ryerson University /Canadá, conheceu a aplicação do jogo e verificou a possibilidade de adaptá-lo à pesquisa no Brasil. A mesma relata que este jogo é aplicado para estimular a comunicação de forma lúdica, entre surdos e não surdos, por interpretação de imagens, na sociedade canadense. Nas escolas infantis no Canadá as crianças aprendem um vocabulário básico em ASL, o que auxilia na inclusão das crianças Surdas e na sua mais rápida aceitação pelo grupo.

O Librário possui dois baralhos, um com o campo semântico generalizado e o outro com o campo semântico da arte. Propõe-se a aplicação do jogo "Librário" como recurso didáticopedagógico no ensino inclusivo, incentivando a aprendizagem da linguagem Libras por pessoas "ouvintes" e valorizando o estudo das imagens e dos elementos como estímulo para as Artes Visuais, fomentando também debates e trocas de opiniões sobre essa área de conhecimento.

O estudo das imagens referentes às palavras utilizadas no baralho de campo semântico generalizado evidencia e propõe o reconhecimento da relação entre imagens figurativas e substantivos concretos. Diferentemente da palavra subjetiva que não possui uma imagem que a ilustre, para ela existem as imagens abstratas. Com o baralho do campo semântico da arte busca-se promover a inclusão do Surdo em diálogo por imagens e sinais trabalhando com os elementos básicos da comunicação visual como: ponto, linha, forma, cor, textura, dimensão, movimento, além dos meios da arte visual como: pintura, desenho, gravura, escultura e instalação.

Dentro deste contexto artístico em junção com a Libras, promove-se a aproximação com a comunidade surda e a participação da inclusão de pessoas surdas brasileiras, mas que não falam o português. Como exemplo, as imagens do Librário no ensino da arte, demonstrado nas figuras 2 e 3, o sinal em Libras da palavra "abstrato" e o quadro abstrato do artista Ternero (2014). 


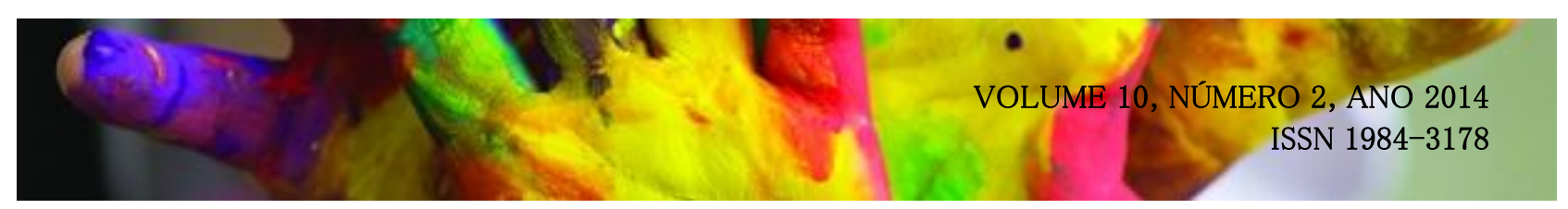

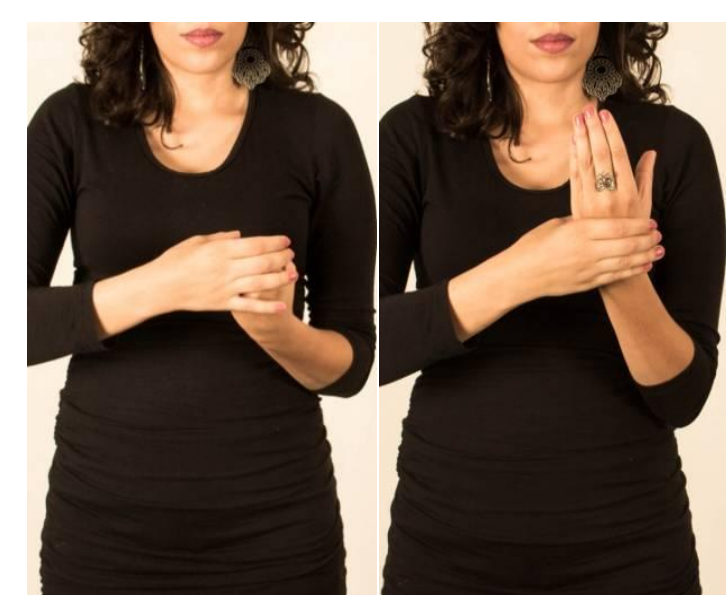

Figura 2: Sinal em Libras da palavra "abstrato". Fonte: Acervo da pesquisa, 2014.

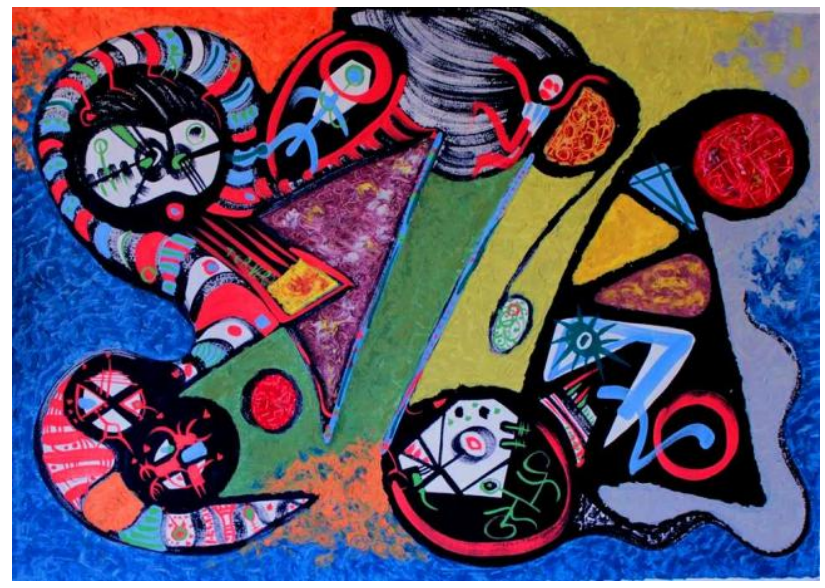

Figura 3: Quadro abstrato - Ternero (2014). Fonte: Acervo da pesquisa, 2014.

$\mathrm{Na}$ perspectiva de contribuir com a comunicação e o ensino das Artes em escolas, a aplicação do jogo Librário foi desenvolvida em etapas descritas na sequencia: Encontro com os professores e orientadores das escolas selecionadas, para esclarecimento sobre a aplicação do jogo Librário e sua importância na comunicação e na arte; Encontros previamente estruturados com alunos e professores, encontros por grupo nas escolas definidas, utilizando de uma aula/hora em disciplinas definidas pela instituição, para cada encontro; Apresentação de uma síntese em vídeo sobre o contexto da pesquisa para alunos e professores; Apresentação das possibilidades de utilização do Librário em jogos e divisão dos grupos de alunos para participação de todos; Aplicação dos jogos Saci, Pescaria e Memória, através do Librário do campo semântico generalizado sequencialmente, conforme o número de alunos e dinâmica da turma; Avaliação do aprendizado das palavras na linguagem da Libras pelos alunos participantes, em debates pósatividades, registrados em gravações sonoras, para uso exclusivo da pesquisa; Finalmente, elaboração de relatórios parciais para os parceiros e artigos científicos para compartilhar e divulgar os resultados parciais da pesquisa.

\subsection{INSTRUÇÕES PARA USO DO JOGO LIBRÁRIO}




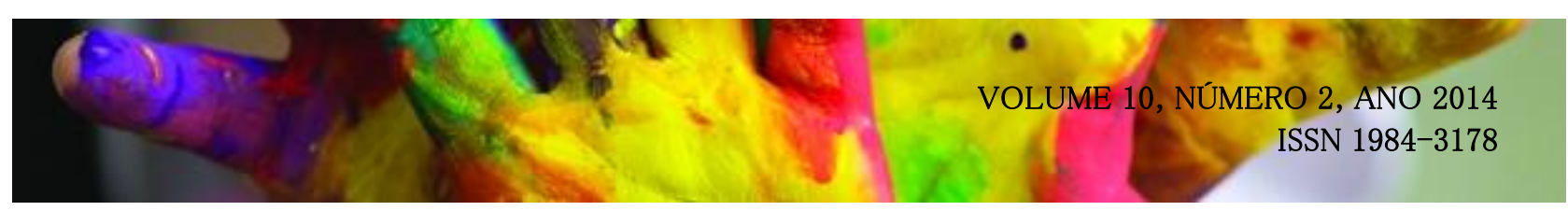

O jogo de baralho da linguagem visual Librário, foi elaborado para ser utilizado em 3 (três) formas de jogar, descritas no "manual do jogo Librário" e transcritas na sequencia:

\subsubsection{Jogo Saci:}

O Saci é um personagem do folclore brasileiro, e em sua lenda vive sozinho na floresta fazendo suas peripécias. O baralho é composto por 54 (cinquenta e duas) cartas com imagens de significados aos pares. Uma das cartas do Saci (o par do Saci) é retirada do baralho. São embaralhadas as demais cartas e distribuídas até que todas as cartas acabem. Cada jogador deverá remover todos os pares completados, colocando-os virados com a face para baixo. O jogador que começar o jogo deverá espalhar as suas cartas na mesa com as faces viradas para baixo. Depois, deverá oferecer as cartas que ficaram para o jogador do lado esquerdo, que terá que tirar uma carta. Se a carta completar um par, o par é colocado na sua frente, de face para baixo. Este jogador deverá abrir o leque de suas cartas, para que o jogador do lado esquerdo possa tirar. Cada jogador que realizar os pares de suas cartas deverá retirá-las das mãos, até conseguir ficar sem nenhuma. Este é o ganhador. O processo de formação de pares continua até que um jogador é deixado segurando a carta do Saci. O jogador que ficar com a carta do Saci é o perdedor.

\subsubsection{Jogo Pescaria:}

Embaralhe as 54 (cinquenta e quatro) cartas e distribua 5 (cinco) delas para cada pessoa, por exemplo, 7 (sete) cartas para 2 (dois) jogadores. O jogador à esquerda, de quem distribuir as cartas, começa o jogo pedindo 1 (uma) carta a 1 (um) dos jogadores escolhido, para fazer par com uma carta que estiver em sua mão. Se o jogador tiver esta carta, deverá entregá-la. O jogador da vez colocará o par da carta de face para baixo, e pedirá novamente a outro jogador. Se o jogador não tiver a carta, deverá dizer "Vá pescar!". Então, o jogador da vez deverá tirar uma carta do monte de cartas. Se ele tirar a carta requerida, ele deverá colocar a carta de face para baixo e pedindo novamente. Caso contrário, deverá esperar a próxima rodada. Os pares formados no início do jogo, ou formados sem necessidade de pedir (que já estejam na mão do jogador da vez), são colocados de face para baixo, no início da vez do jogador. Os jogadores se revezam pedindo cartas e formando pares até as cartas acabarem de um dos jogadores ou termine o monte. Vencerá o jogador com maior 


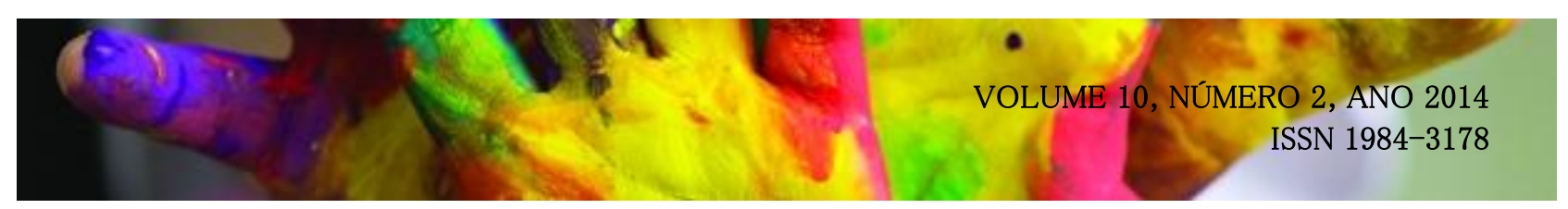

número de pares.

\subsubsection{Jogo Memória:}

Embaralhe as 52 (cinquenta e duas) cartas do baralho, coloque-as com a face para baixo. $\mathrm{O}$ jogador à esquerda, de quem distribuiu as cartas, começará o jogo virando duas cartas para cima. Se esta formar o par, deverá jogar novamente. Se não, passará a vez de jogar para o próximo jogador. O processo continuará até que termine o número de cartas. O jogador que formar maior número de pares será o vencedor.

É importante mencionar que, todas as vezes que as cartas dos jogos (“Saci” e "Memória") formarem um par, o jogador deverá sinalizar em Libras o par formado. No caso do jogo "Pescaria", os jogadores devem se comunicar em Libras para pedir as cartas e responderem uns aos outros. Assim, com a repetição dos sinais durante os jogos a aprendizagem da Libras é feita de forma natural e mais efetiva.

Exemplo: para expressar a palavra professor, considera-se que os participantes do jogo saibam o significado da função de um professor. Assim, a carta da palavra "professor - em desenho" faz o par com a carta do "professor - fotografia do sinal em Libras", conforme sequencia de imagens, representando o "professor" na figura 4. Para que não ocorram dúvidas, a carta "professor - em desenho" também possui uma marca d'água do gesto em Libras.

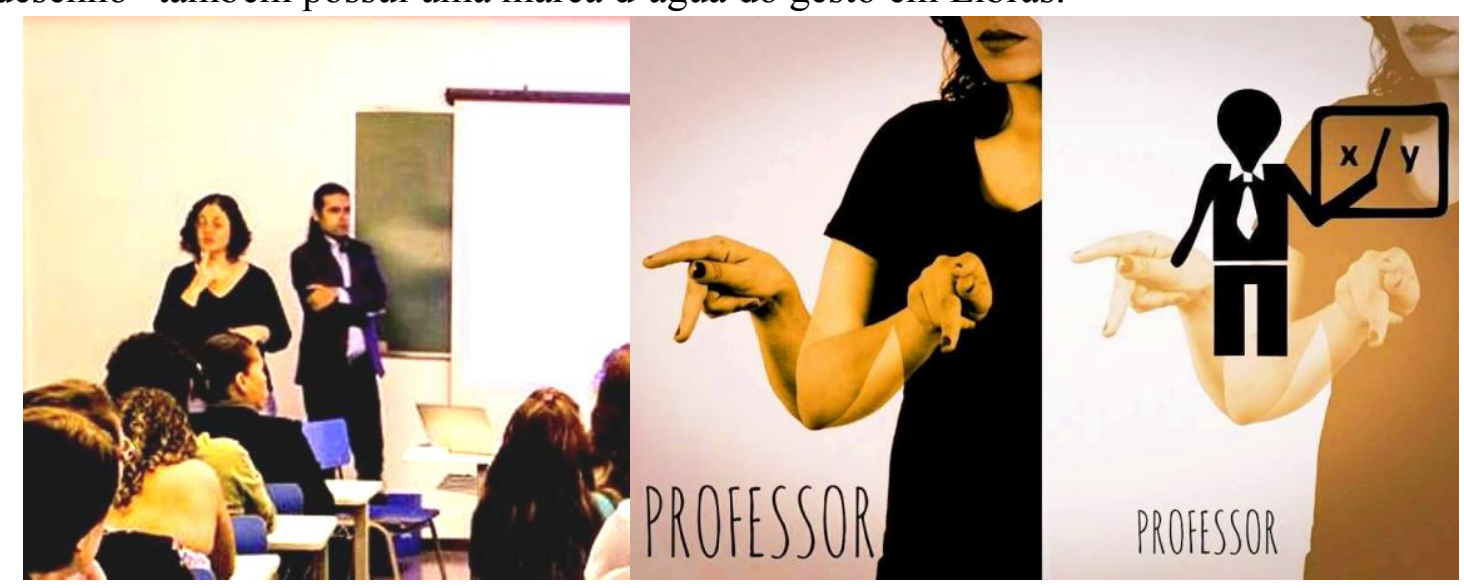

Figura 4: Imagem do professor (função), carta da palavra "professor - em desenho" que faz o par com a carta do "professor - fotografia do gesto em Libras".

Fonte: Acervo da Pesquisa, 2014. 


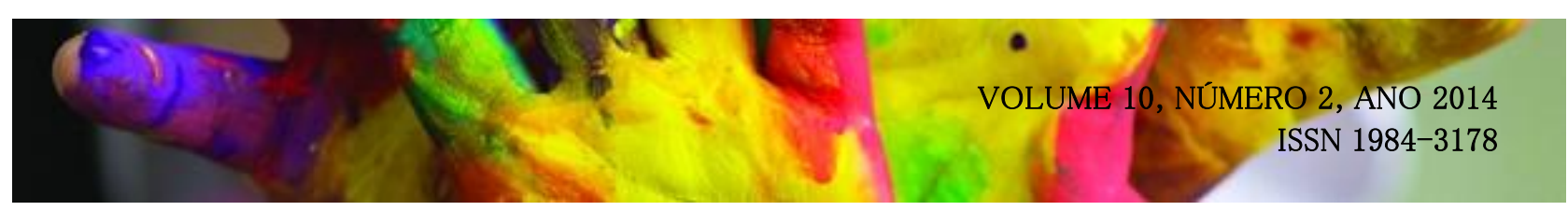

\subsection{DESENVOLVIMENTO DA IDENTIDADE VISUAL}

O nome "Librário" é um neologismo criado pela equipe do projeto, que na prática é um pequeno dicionário bilíngue Libras/Português e Português/Libras. No desenvolvimento das atividades da pesquisa, buscou-se experimentar métodos para melhorar a comunicação entre os indivíduos que escutam e os Surdos sinalizados que moram no Brasil, mas que necessariamente não falam o português (seja pelo uso de equipamentos tecnológicos que auxiliem nessa tradução ou pelo caminho das ideias).

A linguagem visual é um dos caminhos e na teoria da comunicação, um signo, um símbolo ou um ícone pode nos dizer muitas coisas e uma simples imagem pode representar uma marca, e é essa linguagem a norteadora do projeto.

A marca "Design inclusivo: deficientes auditivos" trata-se da representação simbólica do projeto. A marca foi desenvolvida a partir da observação dos elementos principais do contexto da pesquisa, com a participação de pesquisadores do projeto, estudantes do curso de Artes Visuais Licenciatura. Após a identificação dos elementos recorrentes no texto, identificaram-se quais as imagens que poderiam comunicar as palavras: ver, sentir, identificar, comunicar e compreender.

Quanto às cores da marca, definiu-se pelo uso do contraste em preto/branco. O preto, por ser a junção de todas as cores em pigmentação, e o branco, por refletir todas as cores do espectro. Esta simbologia também se estabelece na representação daqueles que ouvem e dos que não ouvem, na proposta inclusiva do projeto. A simplificação das cores favorece, também, o custo da produção e replicação da proposta, tornando-a economicamente viável.

A identidade visual da marca utiliza de alguns conceitos semióticos, o "balão de diálogo" simboliza a comunicação, o olho simboliza a visão que sobrepõe à audição. Priorizando simbolicamente e efetivamente, a comunicação visual.

Nas figuras 5 e 6 apresentam-se os resultados do desenvolvimento da marca do projeto de pesquisa e da marca do Jogo Librário, respectivamente, que, até o momento, permanece como forma de identificação e divulgação. Recorda-se que a proposta é participativa, integrando os 


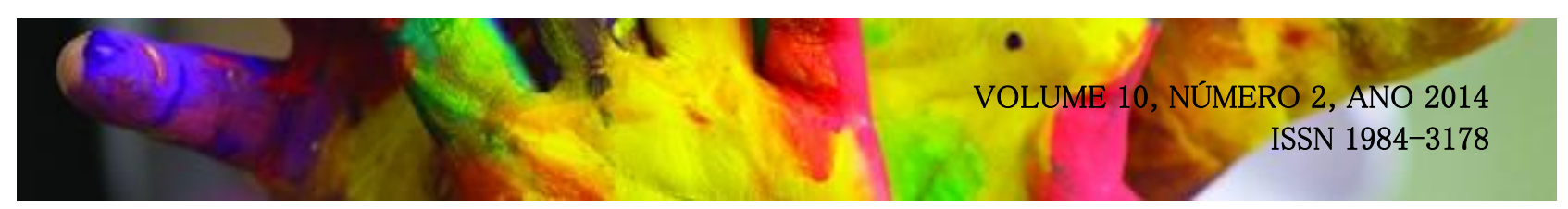

estudantes de Artes Visuais Licenciatura e estudantes de design.

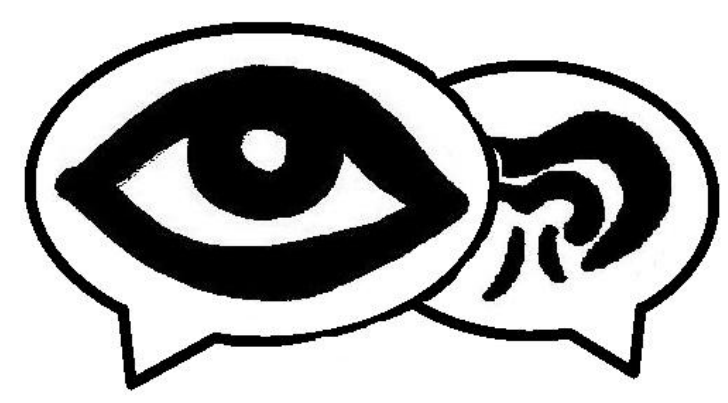

Figura 5: Logomarca do projeto Design inclusivo: deficientes auditivos.

Fonte: Elaborado pela pesquisa, 2014.

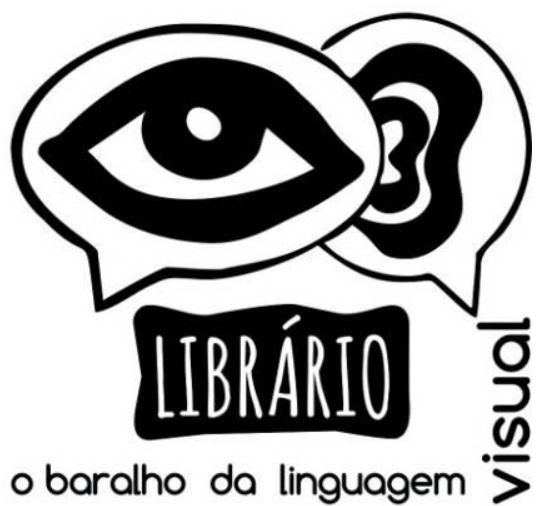

Figura 6: Logomarca do Librário. Fonte: Elaborado pela pesquisa, 2014.

Para divulgação da proposta foram elaborados cartazes e banners, destacando imagens e formas que possam facilitar na compreensão do projeto. Exemplo: símbolos do projeto, imagens dos gestos em Libras, imagens de objetos, imagens de placas de rua, orientações sobre o jogo, etc., conforme figura 7.

Os membros da equipe de pesquisa, estudantes e professores em Artes Visuais Licenciatura e Design, optaram pela concepção do material, a ser utilizado nas oficinas do jogo Librário, com a participação da sociedade. Assim, todo material produzido e atividades desenvolvidas estão registradas na página do projeto "Design inclusivo: Deficientes auditivos" da rede social Facebook ${ }^{5}$, aberta à visitação e opiniões.

Pagina do projeto no Facebook "Design Inclusivo: Deficientes Auditivos". Disponível em: <https://www.facebook.com/pages/Design-inclusivo-deficientes-auditivos/1533254720220456?ref=ts\&fref=ts $>$. Acesso em: 29 out. 2014. 

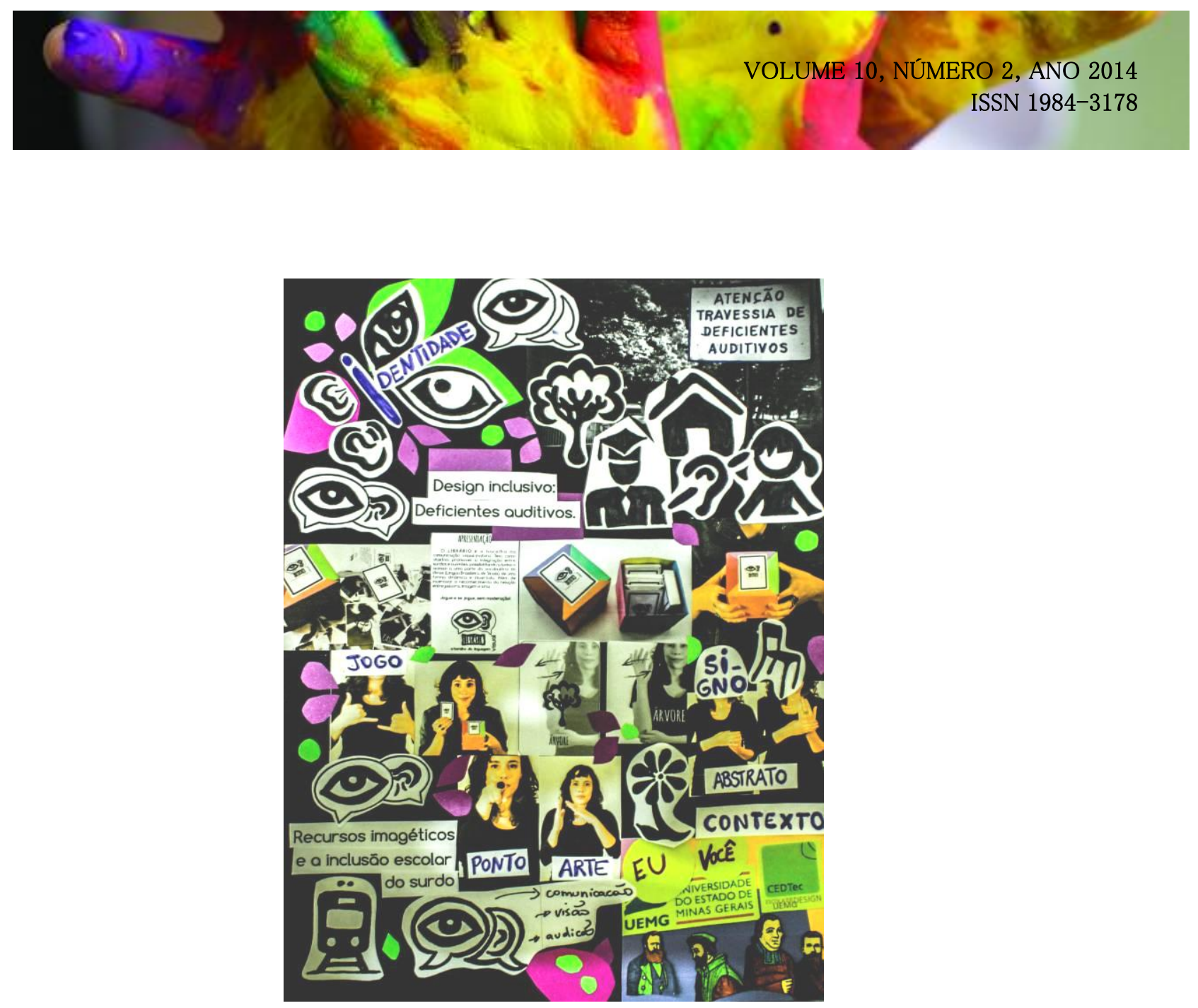

Figura 7: Montagem do Layout de apresentação do Librário. Fonte: Elaborado pela pesquisa, 2014.

\subsection{EMBALAGEM DO JOGO LIBRÁRIO}

O jogo Librário tem como meta contribuir com a difusão da linguagem de Libras em escolas e instituições que compartilham atividades entre pessoas surdas e não surdas. Para tanto, será necessária que a proposta se apresente completa, oportunizando a replicação das cartas para novos exemplares. Definiu-se que além da elaboração das cartas em imagens de desenhos e fotografias de gestos, o jogo necessita de um modelo de embalagem adequado à proposta.

Mestriner (2010) sustenta que o design das embalagens tem impacto no processo de escolha, pois agrega valor ao produto de consumo. É o principal responsável pela percepção final que os produtos terão no mercado. A embalagem consolida a proposta do produto e promove a interface 


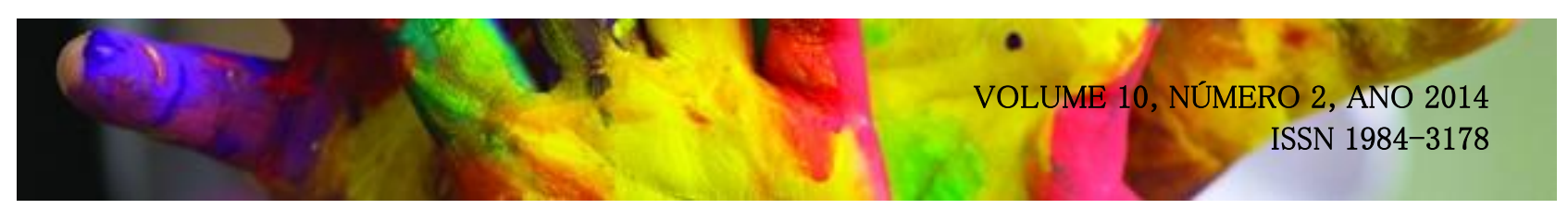

direta com o consumidor no ponto de venda ao evidenciar, em primeiro plano, a marca corporativa.

Gobé (2002) confirma que as funções básicas da embalagem são proteger os produtos enviados da fábrica para os centros de distribuição e os varejistas, exibir e comercializar um produto nas prateleiras das lojas, proporcionar informações importante sobre os produtos e dar sentido global aos atributos emocionais da marca.

A embalagem do Librário é colorida, feita com dobraduras de papéis e tem o objetivo despertar a curiosidade de quem possa jogar, principalmente na escola infantil. Na figura 8, apresenta-se um dos modelos desenvolvidos, para aplicação da proposta em oficinas de jogos.

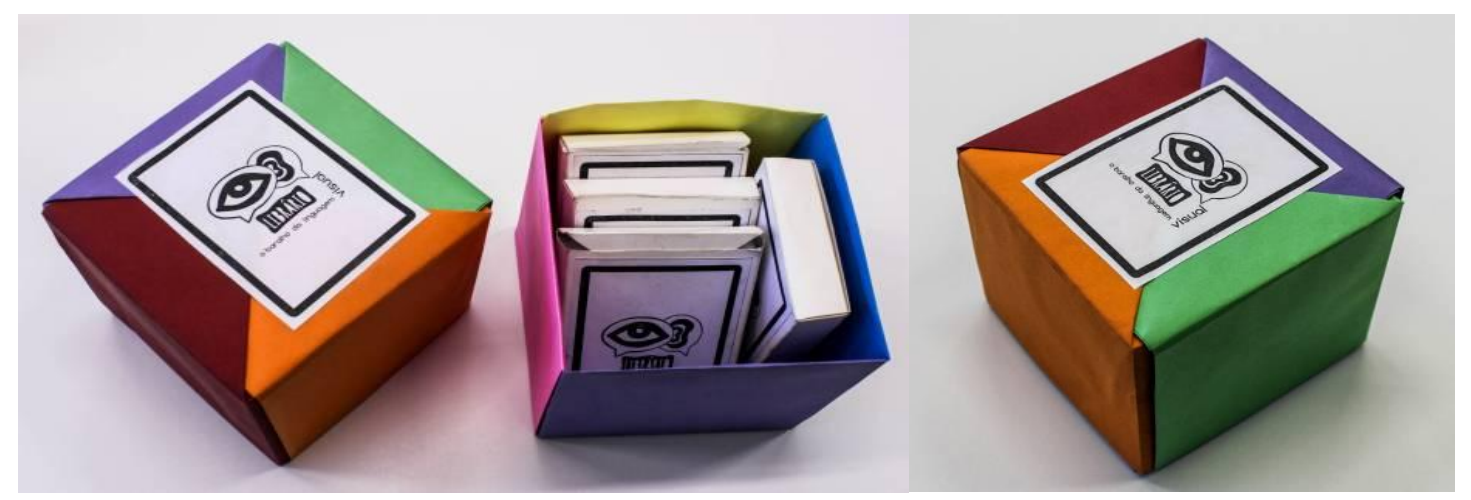

Figura 8: Embalagem do Librário Fonte: Acervo da pesquisa, 2014.

\subsection{VÍDEO “UMA BREVE HISTÓRIA DOS SURDOS NO BRASIL E NO MUNDO"}

A partir da fundamentação teórica da pesquisa, registraram-se algumas curiosidades e fatos históricos importantes, que poderiam ser divulgados na apresentação das oficinas do Jogo Librário, como também em quaisquer outras circunstâncias educativas, para entendimento da sociedade perante o contexto social dos Surdos.

Definiu-se pelo registro em um vídeo de 3:43 minutos, utilizando os recursos do stop 


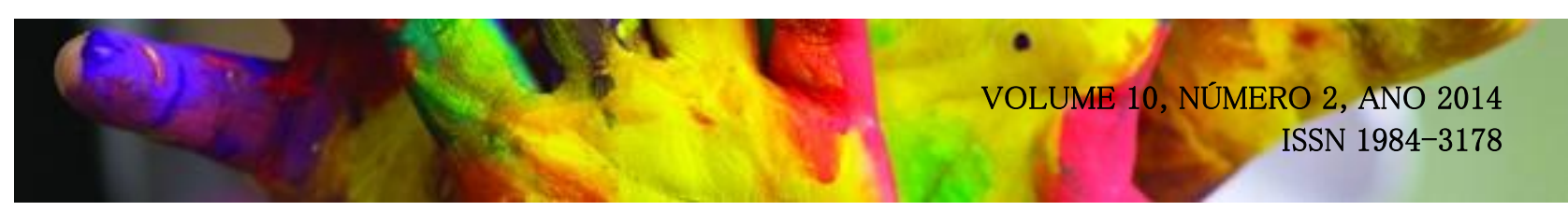

motions, para divulgação na internet, no site do Youtube $^{6}$ e na rede social Facebook, na página específica do projeto.

O vídeo foi elaborado com figuras recortadas em papel e apresentadas na filmagem, com registro sonoro da breve história dos surdos. Foram utilizados os recursos baseados na proposta triangular, desenvolvida por Ana Mae Barbosa, onde procura-se englobar vários pontos de ensino/aprendizagem ao mesmo tempo. Entre os principais estão: leitura da imagem, objeto ou campo de sentido da arte (análise, interpretação e julgamento), contextualização e prática artística (o fazer), segundo Barbosa (1991).

Em nossa vida diária, estamos rodeados por imagens impostas pela mídia, vendendo produtos, ideias, conceitos, comportamentos, slogans políticos etc. Como resultado de nossa incapacidade de ler essas imagens, nós aprendemos por meio delas inconscientemente. A educação deveria prestar atenção ao discurso visual. Ensinar a gramática visual e sua sintaxe através da arte e tornar as crianças conscientes da produção humana de alta qualidade são uma forma de prepará-las para compreender e avaliar todo tipo de imagem, conscientizando-as de que estão aprendendo com estas imagens. (BARBOSA, 1998, p. 17).

A Proposta Triangular O Vídeo foi produzido pela equipe do projeto de pesquisa "Design inclusivo: deficientes auditivos", do CEDTec (Centro de Estudos em Design e Tecnologia) e da monografia "Recursos imagéticos e a inclusão escolar do surdo", do curso de Artes Visuais Licenciatura/UEMG e contextualiza a inclusão da comunidade surda na nossa sociedade. Relata uma síntese do contexto histórico da inclusão dos deficientes auditivos, das leis brasileiras e outras informações. A música utilizada é uma homenagem à Beethoven ${ }^{7}$, músico que ficou surdo. Contextualizam-se as recentes conquistas dos surdos na nossa sociedade, com o objetivo de abrirmos a discussão sobre essa integração em uma sociedade onde a maior parte da população se comunica em uma linguagem vocal-auditiva.

\footnotetext{
${ }^{6}$ Vídeo produzido por Flavia Neves/CEDTec. Uma breve história do surdos no Brasil e no mundo. Postado em; 29 abr. 2014. Disponível em: <https://www.youtube.com/watch?v=RjcWs-aWEAU>. Acesso em: 29 out 2014.

${ }^{7}$ BEETOVEN, Ludwig Von. Sinfonia n ${ }^{\circ} 2$, em D maior, op.36, Scherzo, Allegro. O compositor alemão Ludwig Von Beethoven (1770 - 1827) perdeu a audição progressivamente ao longo de três décadas (entre os 20 e os 50 anos), quando já se encontrava na fase adulta. Como não nasceu surdo, ele tinha memória auditiva suficiente para compor em sua mente, conforme Amorim e Ferroni.
} 


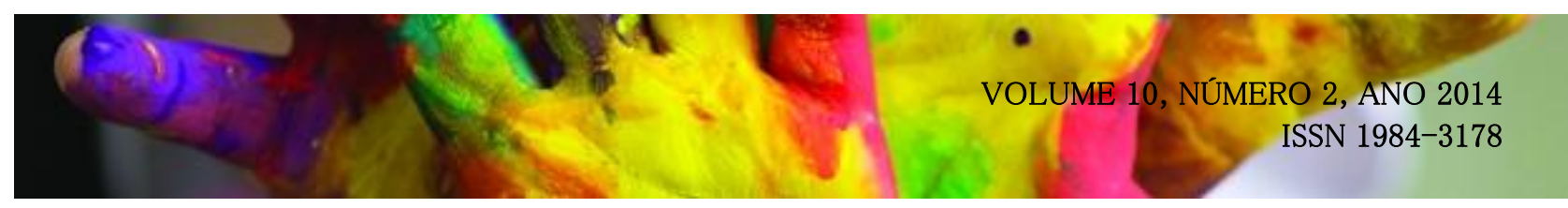

\section{OFICINAS DE APLICAÇÕES DO JOGO LIBRÁRIO}

A oficina poderá ser desenvolvida no espaço de uma sala de aula comum, sendo necessários equipamentos de audiovisual para apresentação do vídeo que contextualiza a história dos surdos e o Jogo de cartas Librário. É importante enfatizar que deve ser feito o sinal durante o desenvolvimento do jogo, para a memorização dos sinais em Libras contextualizados com palavras do português.

\subsection{Para alunos para alunos do $5^{\circ}$ ano - $2^{\circ}$ Ciclo - Ensino Fundamental, da Escola Municipal Júlia Paraíso - Regional Pampulha em Belo Horizonte/MG:}

Neste ambiente, registrou-se a presença de uma aluna (12 anos) que é surda profunda. A jovem utiliza de uma intérprete de Libras que a acompanha em todas as aulas. Observou-se o bom relacionamento dos demais alunos com a jovem e vice-versa. Os alunos se interessaram pela execução da atividade, sendo que, alguns já conheciam a linguagem de Libras, influenciados pela presença da aluna surda na sala de aula. Na avaliação, a estudante surda comentou que o jogo foi muito divertido e que sentiu feliz com sua língua valorizada.

\subsection{Para alunos de Artes Visuais - Licenciatura do $8^{\circ}$ período, da Universidade Estadual de Minas Gerais:}

De acordo com a lei de 2005, $\mathrm{n}^{\circ} 5626$ decreta que "a Libras deve ser inserida como disciplina curricular obrigatória nos cursos de formação de professores para o exercício do magistério, em nível médio e superior, e nos cursos de Fonoaudiologia, de instituições de ensino, públicas e privadas, do sistema federal de ensino e dos sistemas de ensino dos Estados, do Distrito Federal e dos Municípios". O jogo foi aplicado durante a aula da Disciplina de Libras e os alunos apoiaram a iniciativa. A ideia do jogo é dar suporte também para futuros professores em turmas e escolas inclusivas, conforme imagens da figura 9. 

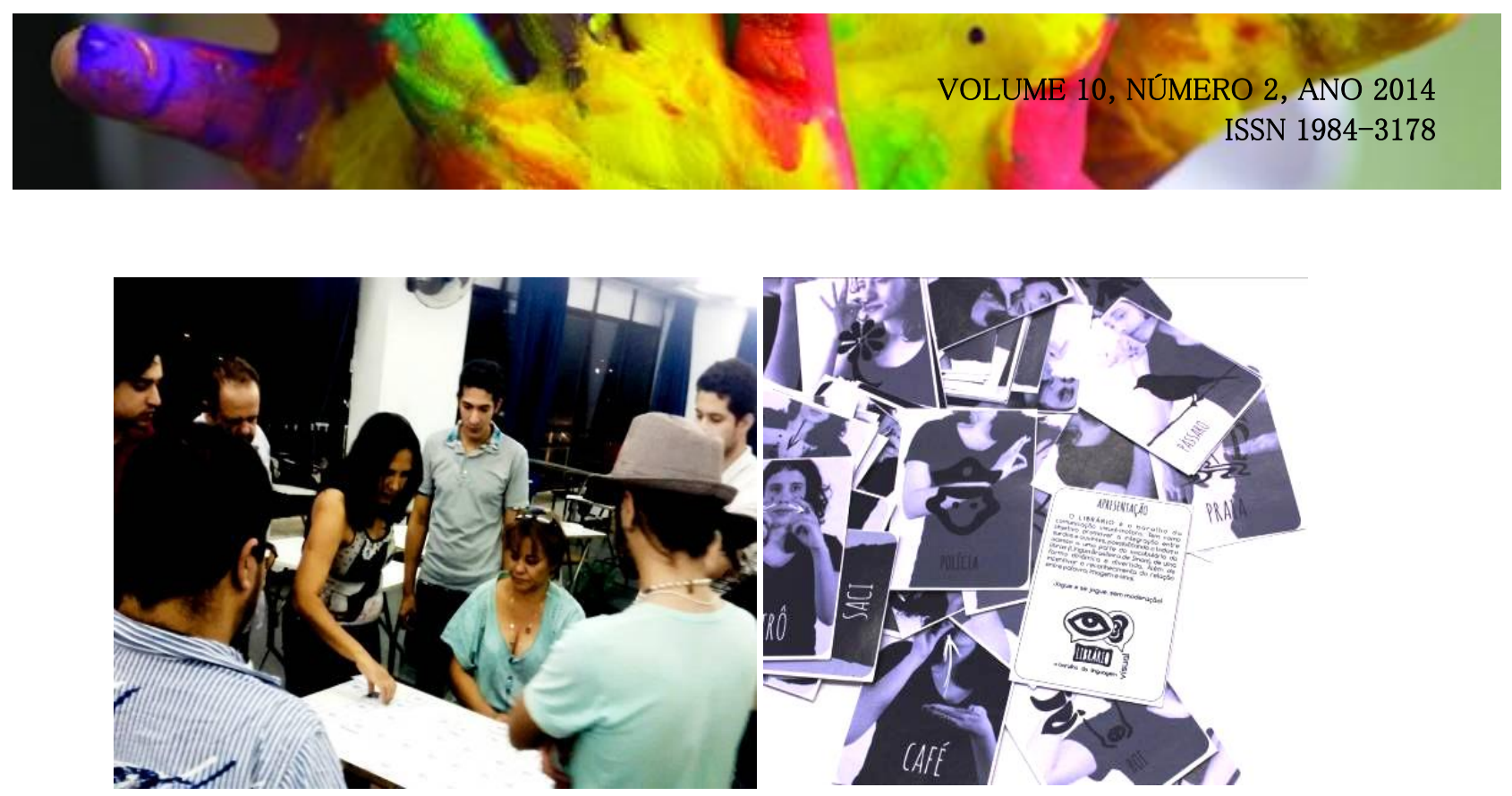

Figura 9: Aplicação do jogo para alunos do Curso de Artes Visuais Licenciatura/UEMG. Fonte:Acervo da pesquisa, 2014.

Nesta experiência, notou-se o interesse na compreensão dos gestos pelos participantes, sabendo-se que é provável que na atuação profissional, venham a conviver com alunos surdos. Algumas sugestões foram compartilhadas, como o tempo para aplicação do jogo em aula e a localização dos estudantes durante a oficina.

\subsection{Para alunos adultos do curso de Libras, do projeto "LIBRAS NA ESCOLA E NA VIDA"}

A Oficina de Libras é realizada aos sábados, à tarde, sendo que uma vez ao mês ocorre um encontro dos profissionais da língua Libras: tradutores, intérpretes, instrutores e professores de

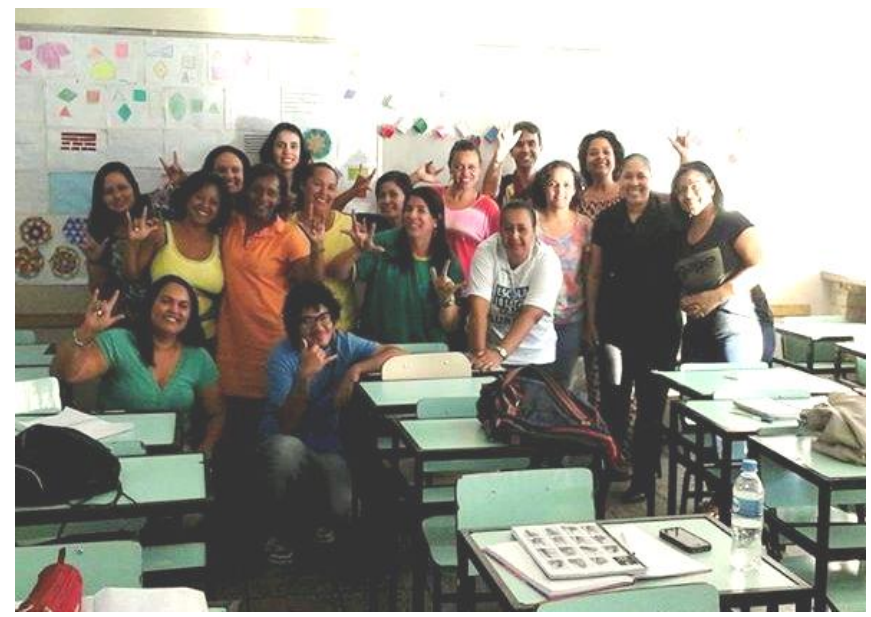

Figura 10: Oficina do projeto "Libras na Escola e na Vida" Fonte: Acervo da pesquisa, 2014. 


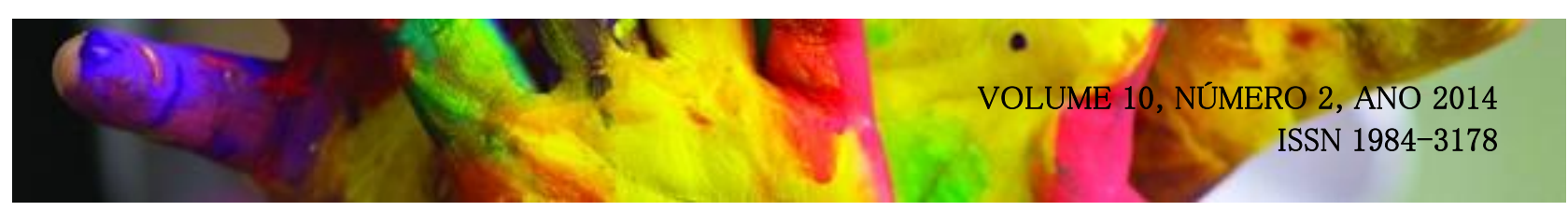

Libras, figura 10. São estudados conteúdos básicos para o aprendizado da Libras. São tratados inclusive os conteúdos relacionados ao: dinheiro, moeda, cartão de crédito, banco, etc. Neste ambiente, o resultado da aplicação do Jogo do Librário foi considerado um sucesso, pois ocorreram contribuições na participação de todos os participantes.

\subsection{Apresentação do jogo no evento organizado pelo sistema FIEMG, a $8^{\circ}$ Olimpíadas do conhecimento,}

No evento da $8^{\mathrm{a}}$ Olimpíada do Conhecimento, em Belo Horizonte/Minas Gerais, profissionais de diversas áreas apresentaram pesquisas e experiências no auditório montado no Cyber Café. Neste evento, o projeto "Design Digital para Inclusão de deficientes auditivos" foi convidado para proferir uma palestra, no dia 05 de setembro de 2014. A palestra "Jogos e soluções em Design para pessoas com deficiência auditiva", foi proferida pela coordenadora e professora Rita de Castro Engler e a estudante de Artes Visuais Licenciatura e bolsista do projeto, Flavia Neves de Oliveira Castro. Ao final da palestra os jogos foram disponibilizados para conhecimento dos presentes, com a participação da equipe do projeto, despertando a curiosidade e divertimento do público.

Dentro da programação do evento, a equipe do projeto teve a oportunidade de conhecer o produto de inovação "Quiros", no estande Indústria do Futuro, uma das áreas mais visitadas da $8^{\mathrm{a}}$ Olimpíada do Conhecimento. Quiros é uma luva desenvolvida por dois estudantes do ITA - Instituto Tecnológico de Aeronáutica, que traduz a língua dos deficientes auditivos, a Libras, em texto e som. Aparentemente, conforme os inventores Gabriel Ilharco Magalhães, estudante de Engenharia da Computação, e do curitibano Daniel Schwalbe Koda, descrito no site do G1GLOBO.COM, o funcionamento da luva é simples: "são sensores que medem a flexão dos dedos, contato entre eles e aceleração. Depois levam as informações da Libras para um programa de computador que, por sua vez, traduz os movimentos em som e texto." 


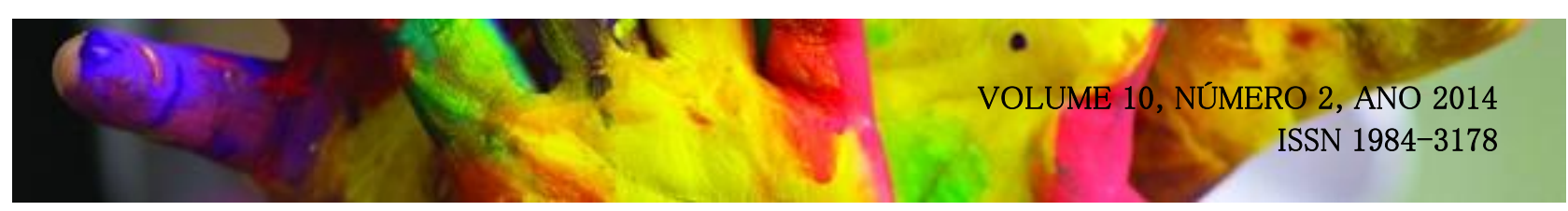

Como inovação para inclusão dos deficientes auditivos, deve-se resaltar o site do INES Instituto Nacional de Educação do Surdo, órgão vinculado ao MEC. Este órgão tornou-se referência do país na área e seu programa desenvolve um projeto que visa facilitar a formação de professores que trabalham na educação dos surdos, preparando inclusive os surdos docentes. O projeto é intitulado de "Manuário", que pretende apresentar novos itens lexicais em Libras. Trata-se de um dicionário acadêmico bilíngue Língua Brasileira de Sinais e Português. A cada episódio, cultura, história e curiosidades sobre a vida de filósofos, pensadores e personalidades marcantes são apresentadas. A novidade certamente irá auxiliar os estudantes surdos, ouvintes e intérpretes, na leitura e aprendizado dos sinais de cada nome escolhido. O material pode ser consultado nos links virtuais da INES, com vídeos educativos traduzidos.

\section{CONSIDERAÇÕES FINAIS}

Nos estudos sobre a Arte, nessa pesquisa, ela é vista como área de conhecimento potencializada em diferentes papéis na sociedade. Verificou-se o potencial da arte quanto conhecimento que pode ser construído, uma linguagem a ser experimentada e fruída, uma expressão a ser externalizada e refletida. Este fator foi fundamental para a formação de professores de artes visuais, como também na dinâmica da comunicação entre pessoas surdas e não surdas.

Conclui-se que os elementos das Artes Visuais atuaram como um recurso pedagógico facilitador da educação dos alunos surdos. O desenvolvimento da proposta em produção de um jogo lúdico e participativo como o Librário, foi estruturado com base nos conhecimentos da estética, da linguagem visual, da semântica, ou seja, da Arte como um todo.

Para a aplicação do jogo foi necessário estipular regras de uso lúdico-didático. Esta atividade foi enriquecedora, pois se apropriou da cultura, utilizando jogos populares de fácil compreensão que facilitaram a comunicação entre surdos e ouvintes.

Ainda existe um preconceito quanto à língua de sinais em função do desconhecimento da sociedade. A divulgação da Libras principalmente junto aos pais ouvintes de crianças surdas, pode 


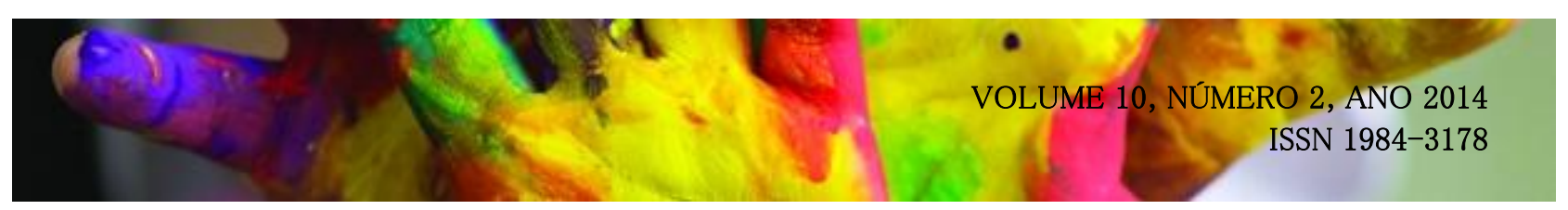

auxiliar numa exposição ainda na infância tênue ao universo dos surdos e sua cultura beneficiando assim o seu desenvolvimento.

O "caráter" de uma língua, para Humboldt, é essencialmente cultural - expressa (e talvez em parte determine) o modo como todo um povo pensa, sente e aspira. No caso da língua de sinais, aquilo que a distingue, seu "caráter", é também biológico, pois se alicerça nos gestos, na iconicidade, numa visualidade radical que a diferencia de todas as línguas faladas. (..) A língua de sinais é para os surdos uma adaptação única a um outro modo sensorial; mas é também, e igualmente, uma corporificação da identidade pessoal e cultural dessas pessoas (HUMBOLDT apud SACKS, 2003, p.105).

Acreditamos que a criança Surda que aprende e cresce se comunicando em Libras é mais saudável, autoconfiante, consciente do seu potencial e das suas singularidades. O Librário é uma opção lúdica-visual para ensinar e divulgar a Libras, considerando que a sua disseminação poderá amenizar o preconceito inerente à sociedade.

A criação da identidade visual proporcionou o uso de tecnologias para a elaboração gráfica, fortalecendo a parceria e a prática dos conhecimentos em Artes Visuais e Design, dos cursos da instituição. Os elementos principais desenvolvidos foram: marca, fotografia, desenhos dos ícones, embalagem, vídeo, página virtual e etc.

Os recursos imagéticos resultantes da aplicação das oficinas proporcionaram uma renovação em conteúdos linguísticos e artísticos, que é intrínseco à comunicação.

Discutiu-se e refletiu-se sobre assuntos concretos e abstratos, e como desfecho a pesquisa enaltece o pensamento de Vygotsky e Sacks. Nós somos a nossa linguagem e a Libras é uma língua vívida, que retrata sentimentos e desenvolve a imaginação. 


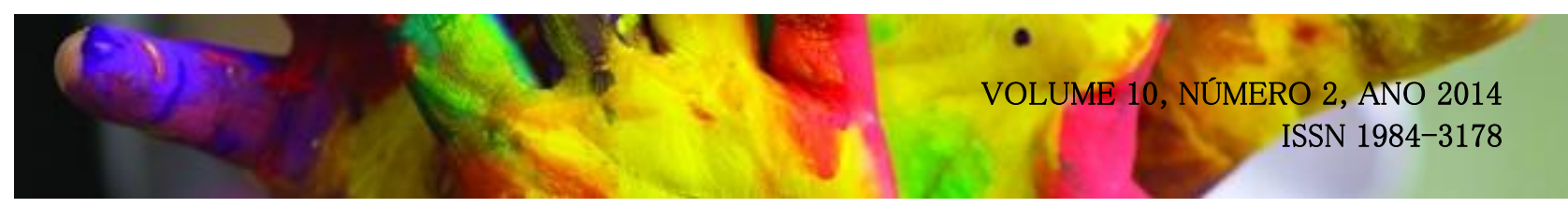

\section{REFERÊNCIAS}

AMORIM, Cristina; FERRONI, Marcelo. Como Beethoven conseguia compor sendo surdo? REVISTAGALILEU.COM. Disponível em: <http://revistagalileu.globo.com/Galileu/0,6993,ECT611093-1716-5,00.html>. Acesso em: 29 out. 2014.

BARBOSA. Ana Mae Tavares Bastos. A imagem do ensino da arte: anos oitenta e novos tempos. $8^{\text {a }}$ edição. São Paulo: Perspectiva, 1991.

BARROS, Manoel Wenceslau Leite de. Gramática: O guardador de águas. $2^{\text {a }}$ edição. Rio de Janeiro: Record, 1998.

BOTELHO, Paula. Educação inclusiva para surdos: desmistificando pressupostos. 2009. Disponível em: <http://proex.pucminas.br/sociedadeinclusiva/anaispdf/educsurdos.pdf >. Acesso em: 10 abr. 2014.

BRASIL, DECRETO No 5.626, DE 22 DE DEZEMBRO DE 2005. Regulamenta a Lei $\mathrm{n}^{\circ} 10.436$, de 24 de abril de 2002, que dispõe sobre a Língua Brasileira de Sinais - Libras e o art. 18 da Lei $n^{\circ}$ 10.098, de 19 de dezembro de 2000. Brasília, 22 dez. 2005. Disponível em: <http://www.planalto.gov.br/ccivil_03/_ato2004-2006/2005/decreto/d5626.htm>. Acesso em 10 out. 2014.

CORSINO, Patrícia. Infância, linguagem e letramento: educação infantil na rede municipal de ensino do Rio de Janeiro. 300f. Tese (Doutorado) Departamento de Educação, PUC-Rio, Rio de Janeiro, 2003.

DAGNINO, Renato. A tecnologia social e seus desafios. In: Tecnologia social. Uma estratégia para o desenvolvimento. Fundação Banco do Brasil, Rio de Janeiro, 2004.

DUARTE JUNIOR, João Francisco. Fundamentos estéticos da educação. São Paulo: Cortez, 1981.

. Por que Arte Educação? 9a edição. Campinas: Papirus, 1991.

GOBÉ, Marc. "Experiências emocionais". D2B Design to Branding Magazine, São Paulo, v. 12, n. 1, p.12-19, Dez. 2006.

G1.GLOBO.COM. Estudantes impressionam Luciano Huck com criação de luva biônica. Disponível em: <http://g1.globo.com/educacao/especial-publicitario/senai/olimpiada-doconhecimento/2014/noticia/2014/09/estudantes-impressionam-luciano-huck-com-criacao-de-luvabionica.html>. Acesso em: 20 out. 2014.

INES - Instituto Nacional de Educação de Surdos. Programa Manuário: dicionário acadêmico 


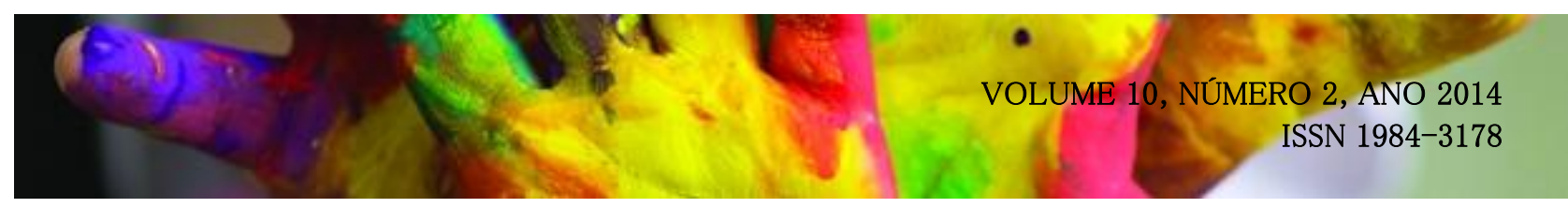

bilíngue Língua Brasileira de Sinais e Português. Disponível em: <http://tvines.com.br/?page_id=333>. Acesso em 10 out. 2014.

LIAVELBERG, Rosa. Para gostar de aprender arte. Porto Alegre: Armed, 2003.

LONG, John Schuyler. The Sign Language: a manual of signs. Iowa City: Athens Press, 1910.

MESTRINER, Fabio. Design de embalagem: curso básico. São Paulo: Makron Books, 2001.

MOURÃO, Nadja. M. Sustentabilidade na produção artesanal com resíduos vegetais: uma aplicação prática de design sistêmico no Cerrado Mineiro. 2011. 206f. Dissertação (Mestrado em Design) - PPGD/Universidade do Estado de Minas Gerais, Belo Horizonte, 2011. Disponível em: <http://www.ppgd.uemg.br/wp-content/uploads/2012/08/Nadja-Maria-Mour\%C3\%A3o.pdf >. Acesso em: 10 out. 2014.

NAD - NATIONAL ASOOCIATION OF THE DEAF. Disponível em: <http://nad.org/>. Acesso em: 20 out. 2014.

PIAGET, Jean. A formação do símbolo na criança, imitação, jogo, sonho, imagem e representação de jogo. São Paulo: Zahar, 1971.

. A formação do símbolo na criança. Rio de Janeiro: Zahar Editores, 1975.

SACKS, Oliver. Vendo Vozes: uma viagem ao mundo dos surdos. São Paulo: Companhia das Letras, 1998. Tradução Laura Teixeira Motta. São Paulo: Companhia das Letras, 2010.

TERNERO - Pseudônimo. 2014. Abstrato. Tela 100 x $72 \mathrm{~cm}$, acrílica e cera de abelha. Disponível em: $<\mathrm{https}$ //www.facebook.com/ternerojoaobosco/photos/pb.664819706925962.2207520000.1417446653./664864070254859/?type=3\&theater >. Acesso em: 20 out. 2014 .

VERGARA, Sylvia Constant. Projetos e relatórios de pesquisa em administração. $5^{\text {a }}$ edição. São Paulo: Atlas, 2004.

VYGOTSKY, Lev. A construção do pensamento e da linguagem. São Paulo: Martins Fontes. (Trabalho original publicado em 1934) 2001.

\section{AGRADECIMENTOS}

CAPES - Coordenação de Aperfeiçoamento de Pessoal de Nível Superior FAPEMIG - Fundação de Amparo à Pesquisa do Estado de Minas Gerais

CEDTec - Centro de Estudos em Design \& Tecnologia da Escola de Design/UEMG 